\title{
Carbonate Buildups in the Pernambuco Basin, NE Brazil
}

\author{
BRUNO V. BUARQUE, JOSÉ A. BARBOSA, JEFFERSON T.C. OLIVEIRA, \\ JOSÉ R.G. MAGALHÃES and OSVALDO J. CORREIA FILHO
}

\author{
Universidade Federal de Pernambuco/UFPE, Departamento de Geologia, LAGESE, Avenida \\ Prof. Moraes Rego, 1235, Cidade Universitária, 50740-530 Recife, PE, Brazil
}

Manuscript received on August 8, 2016; accepted for publication on November 21, 2016

\begin{abstract}
The Pernambuco Basin represents one of the most prominent regions for deep water oil and gas exploration off the Brazilian coast. This study aims to identify and describe the occurrence of carbonate buildups in the offshore regions of the basin. The study was based on an analysis of a set of 143 2D timemigrated seismic sections that cover the offshore region of the Pernambuco Basin. An interpretation of the seismic dataset was used to define the main seismic sequences related to the main regional pulses of deposition and to identify three main groups of carbonate buildups: 1) shelf margin reefs, 2) patch reefs, and 3) isolated carbonate buildups. The carbonate buildups formed in two main intervals during postrift sequences of the Santonian-Maastrichtian and Paleocene-Middle Miocene, which extend the known periods of carbonate deposit formation in the basin. The formation of carbonate buildups was controlled by the tectonic evolution of the Pernambuco Plateau, which created a series of paleotopographic highs that enabled the establishment of oceanographically and climatically favorable conditions for carbonate formation and deposition. These findings are important for understanding the evolution of the basin and for future evaluations of its petroleum potential.
\end{abstract}

Key words: Carbonate buildup, Pernambuco Basin, Brazilian margin, seismic stratigraphy.

\section{INTRODUCTION}

The development of a carbonate platform is dictated by a combination of many factors, including tectonics, eustasy, basinal physiography, oceanography and climatic conditions (Fulthorpe and Schlanger 1989, Sun and Esteban 1994, Wilson 2002, Bachtel et al. 2004). These factors contribute to different types of carbonate depositional systems, from isolated platforms to rimmed shelf systems,

Correspondence to: Bruno Varela Buarque

E-mail: bv.buarque@gmail.com as well as a full spectrum of variations in between (Pomar 2001, Bosence 2005). Methodologies for identifying these structures in seismic data have greatly advanced due to interest by the petroleum industry (Saller et al. 2004, Melville et al. 2004). The discovery of important oil fields associated with carbonate buildup has driven efforts in academic research to study ancient and recent examples of carbonate systems in rift marginal basins (Sarg et al. 1995, Kuznetsov 1997, Kusumastuti et al. 2002, Zampetti et al. 2004, Ronchi et al. 2010, Burgess et al. 2012). 
The Pernambuco Basin forms part of the eastern portion of the Brazilian continental platform. This region is found along the eastern border of the Borborema tectonic province (Almeida et al. 1981, Santos et al. 2010) (Fig. 1). The region is claimed to be the last continental link between South America and Africa before the final separation and formation of the South Atlantic Ocean (Fainstein and Milliman 1979, Rand and Mabesoone 1992, Mabesoone and Alheiros 1993, Lima Filho 1998, Matos 1999, Nascimento 2003). The Pernambuco Basin is an area of hyper-extended continental crust forming a region called the Pernambuco Plateau (Fainstein and Milliman 1979, Gomes et al. 2000, Oliveira 2013, Magalhães et al. 2014), which represents one of the most prominent frontiers for deep water exploration off the Brazilian coast (MME-EPE 2012). The geology of the Pernambuco Basin in offshore domains is unknown due to the lack of stratigraphic wells. The main tectono-stratigraphic characteristics of the plateau region are based on interpretation of seismic data and geophysical surveys (Córdoba et al. 2007, Magalhães et al. 2014, Buarque et al. 2016). The inferred model for the basin suggests that the rift deposits are AptianAlbian in age and are related to two rift phases (Maia et al. 2012, Buarque et al. 2016). The plateau basin also has a salt layer with large halokinetic features, such as diapirs and salt domes (Córdoba et al. 2007, Buarque et al. 2016). Although carbonate rocks have been found in the onshore region of the Pernambuco Basin in outcrops and stratigraphic boreholes (Lima and Pedrão 1989, Lima Filho 1998, Córdoba et al. 2007, Barbosa et al. 2008, Maia et al. 2012), the occurrence of carbonate deposits has never been studied offshore of the Pernambuco Basin. This paper aims to identify and describe a series of structures that we had identified as large carbonate buildups. The objectives were to verify the occurrence of carbonate structures (mainly based on morphology), suggest a classification and determine their possible age according to stratigraphic inferences. Our methodological approach was mainly based on the analysis of 2D seismic reflection data covering the plateau region. The results allowed us to create a map depicting the main occurrences of buildups, classify the occurrences into 3 types of morphologies and infer the age of their formation. These carbonate buildups represent important oil and gas sources in many sedimentary basins (Kusumastuti et al. 2002, Saller et al. 2004, Ronchi et al. 2009, Burgess et al. 2013, Jamaludin et al. 2014, Koša et al. 2015, Saqab and Bourget 2015), and the structures revealed here can be investigated as hydrocarbon reservoirs in the future.

\section{GEOLOGICAL SETTING}

The Pernambuco Basin is located in the eastern part of the Borborema Province, which represents the northeastern portion of the South American Platform (Almeida et al. 1981, Van Schmus et al. 2008, Santos et al. 2010, Araujo et al. 2013) and is located in northeastern Brazil (Fig. 1). The Borborema Province is regarded as a structural province consisting of a complex collage of continental masses (Almeida et al. 1981, Santos et al. 2010). Its evolution involved a series of Precambrian orogenic events (Santos et al. 2010, Neves et al. 2012) and late rifting stages that culminated in continental breakup during the Cretaceous (Chang et al. 1992, Matos 1999).

The Pernambuco Basin is separated from the Alagoas Basin to the south by the MaragogiBarreiros High and from the Paraíba Basin to the north by the PESZ (Figs. 1 and 2), and it is linked to the South Domain (SD) (Fig. 1). This basin exhibits a narrow coastal zone that was implanted over a narrow graben, which formed an interior basin in the continental platform (Fig. 2) (Maia 2012, Barbosa et al. 2014, Buarque et al. 2016). The platform break is marked by an outer hinge that runs parallel to the coastline and comprises the Maracatu High. 
The distal offshore region of the Pernambuco Basin developed over a large region of hyper-extended continental crust (Magalhães et al. 2014), which formed the Pernambuco Plateau (Fainstein and Milliman 1979, Gomes 2000, Oliveira 2013), and extends to isobaths of approximately $3000 \mathrm{~m}$ (Figs. 1 and 2). The Pernambuco Plateau comprises at least four main basement lows and a central outer high, called the Gaibu High, which trends E-W (Figs. 2 and 3). Itamaracá High is another important outer high that trends NW-SE and it is located on the northeastern border of the plateau (Fig. 3). The main sets of structures that controlled the Pernambuco Basin's evolution are ductile Precambrian shear zones that trend mostly NE-SW and E-W. These were reactivated as strike-slip and normal faults during the rifting process. The second main group of structures are oblique transfer faults that trend NW-SE (Polônia 1997, Lima Filho 1998). Additionally, normal faults that trend N-S, WNW-ESE and NNW-SSE formed as the basin opened (Figs. 1 and 2).

The sedimentary succession in the coastal zone is mainly represented by siliciclastic formations of Aptian-Albian age, carbonates of CenomanianTuronian age and siliciclastic Neogene deposits (Rand and Mabesoone 1982, Lima Filho 1998, Maia 2012, Barbosa et al. 2014). Interpretation of seismic and potential field data has provided evidence of a significant sedimentary column in the plateau regions, which possibly reaches up to $6 \mathrm{~km}$ in thickness, over the main depocenters of the Pernambuco Plateau (Oliveira 2013, Magalhães et al. 2014). Studies of the coastal zone of the Pernambuco Basin have shown that a magmatic event occurred there during the Upper Albian and generated a series of volcanic rocks that formed the Ipojuca Magmatic Suite (Sial et al. 1988, Lima Filho 1998, Nascimento 2003). The age of the main pulse of this magmatic event is 102-103 my (Long et al. 1986 by $\mathrm{Rb}-\mathrm{Sr}$ isochrons, and Nascimento 2003 by $\mathrm{Ar}^{39} / \mathrm{Ar}^{40}$ zircon fission tracks). Buarque et al. (2016) proposed that this magmatic event continued in plateau regions, forming extrusive and intrusive structures during the post-rift period. Seismic interpretations have also demonstrated the presence of a salt layer covering the center of the Pernambuco Plateau (Buarque et al. 2016), which is most likely Upper Aptian in age.

The Pernambuco Basin can be divided into three main structural domains (Maia 2012, Oliveira 2013, Barbosa et al. 2014):

1) The inner basin, which forms a narrow rift that is parallel to the opening of the South Atlantic. It comprises two different depocenters separated by the Cabo de Santo Agostinho High (Fig. 2). In the coastal zone, this structural high is associated with volcanic rocks intruded into the sedimentary cover and one occurrence of an alkali feldspar granite, known as the Granito do Cabo de Santo Agostinho.

2) The Maracatu High, which forms an elongated outer hinge, trends almost N-S and lies parallel to the coastline (Figs. 2 and 3). This outer hinge, formed by the continental platform, separates the interior basin from the offshore domains.

3) The Pernambuco Plateau, which formed from the hyper-extended continental crust and extends to isobaths of approximately $3000 \mathrm{~m}$ (Fainstein and Milliman 1979, Gomes et al. 2000, Oliveira 2013, Magalhães et al. 2014) (Figs. 1 and 2). The plateau comprises of at least four main basement lows and a major outer high, which trends E-W and is located in its center and is called the Gaibu High. Previous geophysical studies have suggested that this structure was strongly influenced by both intrusive and extrusive magmatism (Figs. 2 and 3) (Oliveira 2013, Magalhães et al. 2014). 


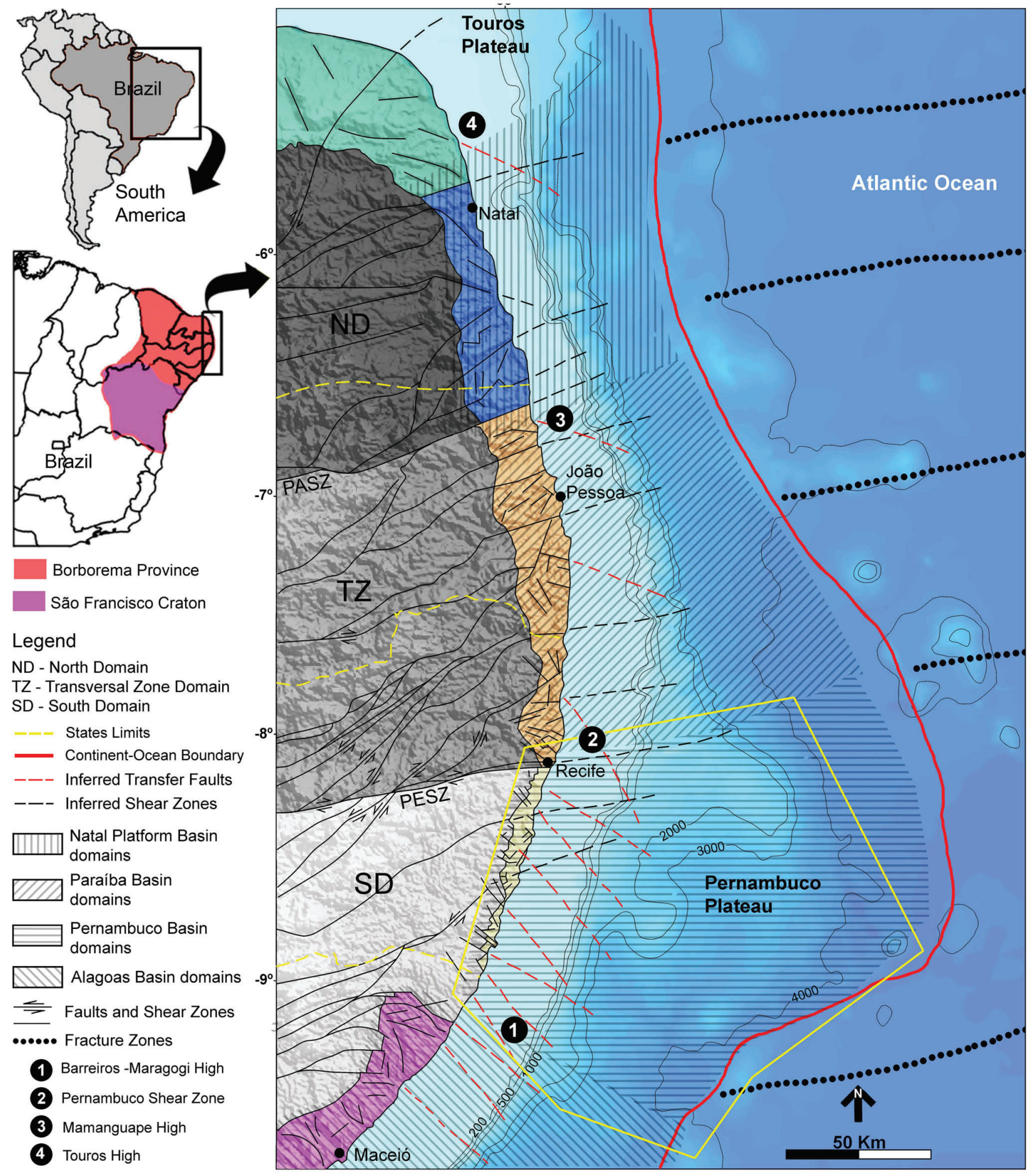

Figure 1 - Location of the Pernambuco Basin (PEB) on the eastern border of Borborema Province (BP). The compartmentalization of the PEB is directly linked to the South crustal domain (SD) of the BP. The basin is bounded by the PESZ and Maragogi-Barreiros structural high. The pink, light-green, orange, blue and dark-green areas represent the coastal zones of the Alagoas, Pernambuco, Paraíba, Natal Platform and Potiguar Basins, respectively. The offshore domain of each basin is depicted by hatched zones. The positions of the COB and fracture zones are from Magalhães et al. (2014). The thin yellow line polygon marks the location of the 2D seismic surveys (study area). 


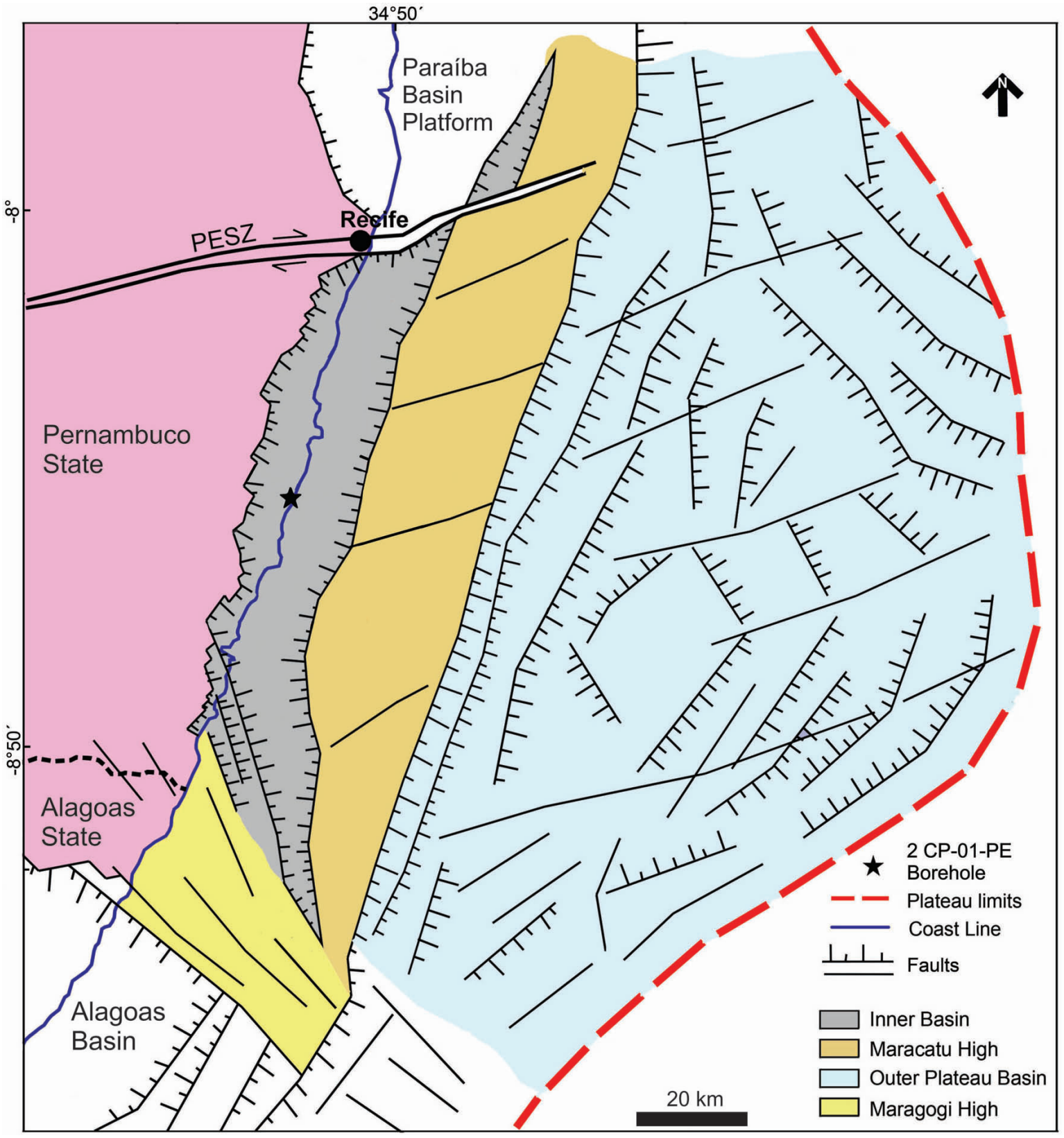

Figure 2 - Tectonic compartmentation of the Pernambuco Basin (modified from Buarque et al. 2016). Three mains domains are depicted: 1) the inner basin; 2) the platform domain formed by the Maracatu High; and 3) the plateau basin.

\section{MATERIALS AND METHODS}

This study is mainly based on the analysis of 143 time-migrated two-dimensional (2D) seismic sections obtained from the Brazilian Repository of Exploration and Production (BDEP) and curated by the National Agency of Petroleum, Natural Gas and
Biofuels (ANP). The set of seismic sections covers almost the entire Pernambuco Plateau. The surveys represent a set of different generations of data with varied qualities and imaging depths, which were integrated to allow for the interpretation of regional features, as well as the basement contour and main seismic sequences. After interpreting the main 
seismic sequences, a set of 59 seismic lines was selected. This set represents the highest imaging quality available, with a total length of $4,339.5 \mathrm{~km}$ (Fig. 3). The selected seismic sections were used to perform a detailed interpretation of the carbonate buildups in the region (Fig. 3) (Burgess et al. 2013). The selected set of $2 \mathrm{D}$ seismic sections has imaging depths that vary from 8-12 s two-way time (TWT) and covers approximately $13.915 \mathrm{~km}^{2}$ of the Pernambuco Plateau (Fig. 3). Post-processing procedures, mainly consisting of frequency filters, were applied to reduce problems related to the signal ratio noise. The approach suggested by Rohrman (2007) based on the use of high-frequency filters helped to distinguish the carbonate buildups from volcanic structures (Buarque et al. 2016), which are abundant in the Pernambuco Plateau. All of the seismic volumes were normalized to represent the peak of the wavelets as the normal polarity.

The interpretation of the seismic sequences and possible ages was based on the stratigraphic relations recorded in the onshore region of the Pernambuco Basin (Lima Filho 1998, Maia et al. 2012, Barbosa et al. 2014) and on the well-studied offshore record of the Alagoas Basin (Campos Neto et al. 2007). This interpretation was tentative; there are no boreholes in the offshore Pernambuco Basin.

The interpretation of the carbonate structures consisted mainly of a systematic description, which was based on the morphology and stratigraphic relation of these structures with the underlying and overlying strata (Saller et al. 2004, Burgess 2013). We adopted the term isolated carbonate buildup as proposed by Burgess et al. (2009). This term refers to carbonate platform strata deposited as a geomorphic feature that shows significant relief relative to adjacent, chronostratigraphicequivalent, and deeper-water strata. Burgess et al. (2009) focused on isolated carbonate buildups with no significant attachment to landmass. In our study, we analyzed carbonate buildups formed in the shelf margin and isolated carbonate buildups formed in the distal Pernambuco Plateau region.

The control exercised by tectonic and eustatic processes in the formation of isolated carbonate buildups are well known in Mesozoic and Cenozoic sequences (Erlich et al. 1990, Kusumastuti et al. 2002, Zampetti et al. 2004, Schlager 2005, Menier et al. 2014, Saqab and Bourget 2015, Courgeon et al. 2016). Shallow marine environments created over platforms and epeiric seas were commonly associated with repeated transgressive pulses (3rd to 4th order),which allowed the establishment and growth of carbonate buildups (Saqab and Bourget 2015). Minor erosional events or major exposures of carbonate buildups are also common due to regressive pulses. The drowning of the carbonate buildups occurs when a fast sea level rise causes the environment to deepen below the photic zone and prevent carbonate formation. Back-stepping and vertical orientation of the carbonate buildups are associated with the drowning processes (Kusumastuti et al. 2002, Zampetti et al. 2004, Menier et al. 2014). The demise of carbonate buildups caused by the complete drowning process normally results in the structure burial by other carbonate deposits or marine shales (Erlich et al. 1990, Campbell and Stafleu 1992, Zampetti et al. 2004). Carbonate buildups and adjacent platforms can undergo multiple events of drowning, and the effect of major flooding can eventually form a drowning unconformity (Erlich et al. 1990, Campbell and Stafleu 1992, Courgeon et al. 2016). The indications of drowning are horizontal to subhorizontal marine onlap reaching the preserved flanks of the structure, and parallel reflectors capping the buildup. High amplitude reflectors marking the onlapped boundary of the buildups are also common (condensed surfaces) (Erlich et al. 1990, Kusumastuti et al. 2002). However, analysis of outcrops, borehole logs and seismic data has shown that identification of the growth, exposure and drowning events of carbonate buildups can 
represent complex challenges and pitfalls (Campbell and Stafleu 1990, Erlich et al. 1990, Zampetti et al. 2004). For example, the limits of strata imaging due to seismic resolution and effect of differential compaction can inhibit correct identification of truncation surfaces and onlap terminations.

\section{RESULTS}

\section{SEISMIC STRATIGRAPHY}

Five main seismic sequences are defined: Sq. 1 rift phase 1 (Barremian-Aptian) and rift phase 2 (Albian), Sq. 2 - Cretaceous post-rift (CenomanianSantonian), Sq. 3 - (Campanian-Maastrichtian), Sq. 4 - Lower Cenozoic post-rift (Paleocene-Middle Miocene), and Sq. 5 - Upper Cenozoic post-rift (Upper Miocene-Recent) (Figs. 1 and 4). The ages of the seismic sequences are based on available data from the onshore portion of the basin and from comparisons with available data from the offshore region of the neighboring Alagoas Basin (Figs. 2 and 3 ).

The deposits of Sq.1 were tilted by the syn-rift faults and have synthetic and antithetic orientations (Fig. 4). The rift sequence is generally represented by discontinuous reflections with low amplitudes and low frequency, disrupted by a large number of faults. In some regions, preserved blocks show locally parallel configurations. In some sections, it is possible to identify the intra-rift unconformity from the top of the first rift phase. An increase in the continuity and frequency of the reflectors can be noted near the top of the Sq. 1 rift sequence, which possibly indicates the beginning of the sag phase deposit formation (Figs. 4 and 5). The occurrence of two rift phases was previously discussed by Maia et al. (2012) and Barbosa et al. (2014) based on evidence found in outcrops and seismic data in the onshore region of Pernambuco Basin.

The first Cretaceous post-rift seismic sequence (Sq. 2) may contain sedimentary deposits of the Albian-Santonian interval. The base of this sequence shows evidence of the most significant flooding pulse in the basin, which is represented in the onshore region by the Estiva Formation (Lima Filho 1998). This pulse is most likely related to the eustatic maximum that occurred during the Cenomanian-Turonian interval, which marked a stage of deep circulation of oceanic waters across the Atlantic Ocean (Pletsch et al. 2001). The Sq. 2 seismic sequence is characterized by continuous internal reflections with medium and low amplitudes and frequencies. These reflections are typically parallel in the proximal region of the basin, transitioning to a free internal configuration with incipient parallel reflections in the distal regions of the plateau (Fig. 4).

The second Cretaceous post-rift seismic sequence (Sq. 3) is most likely represented by sedimentary deposits of the SantonianMaastrichtian interval. In the neighboring Alagoas Basin, this sequence is related to a transgressive event, with its maximum occurring during the Turonian with the deposition of a carbonate ramp (Koutsoukos 1989, Campos Neto et al. 2007) and a regressive event at the end of the Coniacian (Campos Neto et al. 2007) (Figs. 4 and 5). Within this sequence, we found that the main carbonate buildups occurred in the platform region and in paleotopographic highs in the Pernambuco Plateau. Over the platform and in the proximal region of the plateau, the seismic sequence is characterized by continuous internal reflections with high amplitudes and low frequency. In the distal region of the plateau, the sequence transitions to a pattern of free and chaotic reflections.

The Lower Cenozoic post-rift seismic sequence (Sq. 4) comprises deposits of the PaleoceneMiddle Miocene interval. In the neighboring Alagoas Basin, this sequence is mainly related to a regressive event (Campos Neto et al. 2007). Evidence of this regressive cycle has been well recorded in the dipping seismic sections observed herein in the offshore region of the Pernambuco 


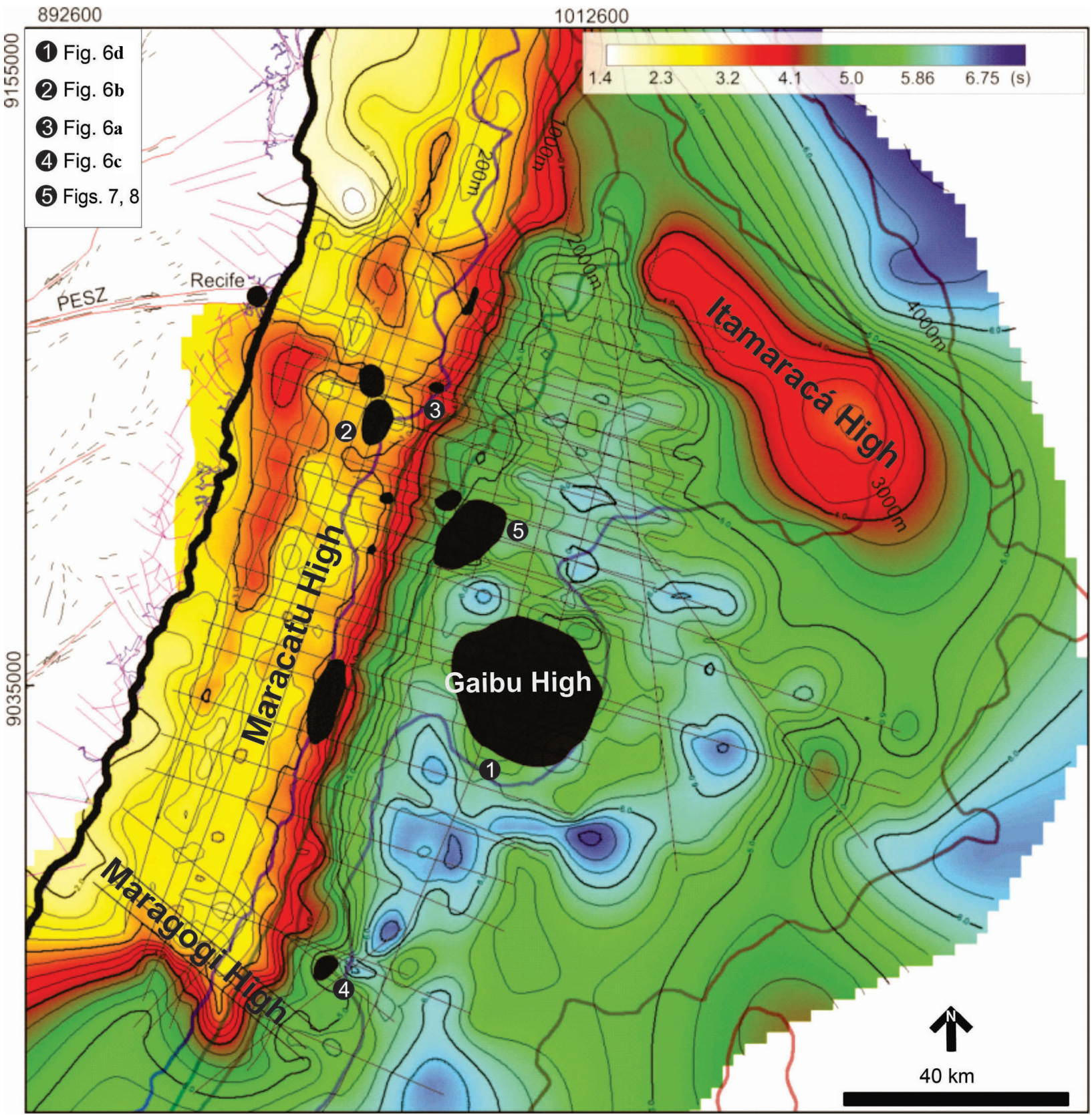

Figure 3 - Map of the seismic basement contours based on the interpretation of 143 time-migrated two-dimensional (2D) seismic sections (depth in time). The main topographic highs and depocenters are shown. The locations of the 59 selected seismic sections are shown; sections were selected to best describe the carbonate buildups (black zones). The dotted black lines mark the extension of Precambrian shear zones towards the platforms. Isobaths at $200 \mathrm{~m}, 2000 \mathrm{~m}, 3000 \mathrm{~m}$ and $4000 \mathrm{~m}$ are shown. Structures in the continent: thin black lines - lineaments, thin red lines - shear zones, and thin pink lines - faults in the onshore region of the marginal basins. 


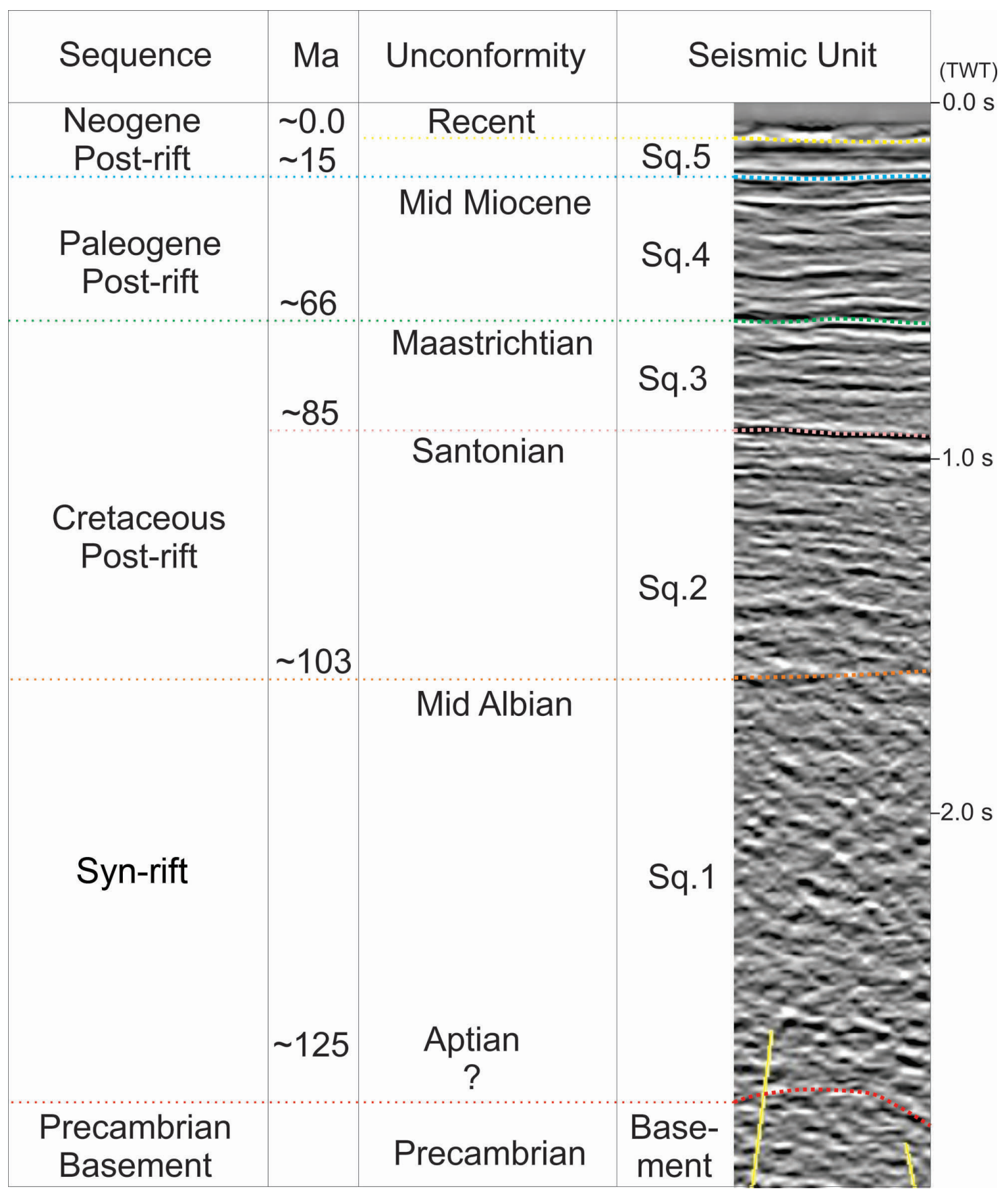

Figure 4 - Definition of the seismic stratigraphic sequences and main unconformities observed in seismic surveys of the Pernambuco Basin. The ages of the sequences are tentatively based on available data from the onshore region of the Pernambuco Basin and the offshore region of the Alagoas basin. 
Basin. We assert that this process mainly affects the platform depositional systems and is dominated by shallow processes, where the progradation of clinoforms can be clearly identified (Figs. 4 and 5). In the north portion of the plateau, this depositional event is limited by an unconformity that may represent a strong erosive event across the basin. This seismic sequence is characterized by a low continuity of internal reflections, a low frequency, and amplitudes ranging from low to medium. The proximal region of the platform is mainly marked by prograding clinoforms and a parallel configuration of internal reflections, passing to an incipient parallel and free internal reflections in distal regions.

The Upper Cenozoic post-rift seismic sequence (Sq. 5) comprises deposits ranging from the Middle Miocene to recent times (Figs. 4 and 5). This depositional sequence has been well studied in neighboring basins, including the Alagoas and Potiguar basins (Feijó 1994, Campos Neto et al. 2007). Over the platform and in the proximal region of the plateau, this sequence is characterized by reflections with good continuity, high amplitudes and low frequency. In the distal region, the sequence is mainly characterized by free to chaotic reflections.

\section{CARBONATE BUILDUPS}

Three types of carbonate buildups were identified in this study with regard to their location in the offshore regions of the basin (Pomar 2001, Kusumastuti et al. 2002, Rosleff-Soerensen et al. 2012): shelf margin reefs, patch reefs and isolated carbonate buildups (Fig. 5). The locations and estimated diameters of the structures are indicated by the black polygons in Fig. 3. Large isolated carbonate buildups were identified based on a few key elements, such as geometry, reflectivity signals and cross-cutting relationships (Saller et al. 2004, Burgess et al. 2013). The identified buildups are in post-rift sequences and are observed to be positioned within an interval ranging from 0.2 to $2.63 \mathrm{~s}$ (TWT). Some seismic reflection aspects are observed in the carbonate buildups, such as continuous high-amplitude capping reflections and onlap termination over their flanks (Figs. 6 and 7).

Shelf margin reefs are found at the borders of the Maracatu High, parallel to the coastline (Figs. 3 and $6 a$ ). These reefs present widths ranging from 1.3 to $4.7 \mathrm{~km}$, lengths ranging from 1.2 to $13 \mathrm{~km}$, and heights ranging from 0.2 to $0.39 \mathrm{~s}$. It is important to highlight that quantification of the morphologic parameters is related to the intersection of the seismic surveys on the carbonate structures. Spacing between the surveys can lead to misinterpretation about the continuity of these structures, which may interfere with the calculation. The length of the margin reef system is most likely larger than what was observed, but because of the spacing between the seismic surveys, this cannot be confirmed.

The shelf margin reefs display mediumamplitude, continuous to sub-continuous, mounded reflections at their tops and low-amplitude internal reflections (Fig. 6a). The identification of onlap termination on the shelf margin reefs is complicated by the presence of interfingering between the deposits forming the carbonate buildup and the surrounding strata (probably siliciclastics), producing what is known as depositional wings or stringers (Burgess et al. 2013, Koša et al. 2015).

Over the Maracatu High and behind the reef barriers in the shelf margin, two large carbonate buildups were found, interpreted here as patch reefs, forming a back-reef zone (Figs. 3 and 6b). Their length ranges from 4 to $9.5 \mathrm{~km}$ and width ranges from 4.3 to $5.7 \mathrm{~km}$, with a mean height of $0.23 \mathrm{~s}$. The patch reefs display continuous and high-amplitude seismic reflection at its flat tops and continuous to semi-continuous, medium to high amplitude seismic reflections in the structure interior. Some small patch reefs are indicated only 


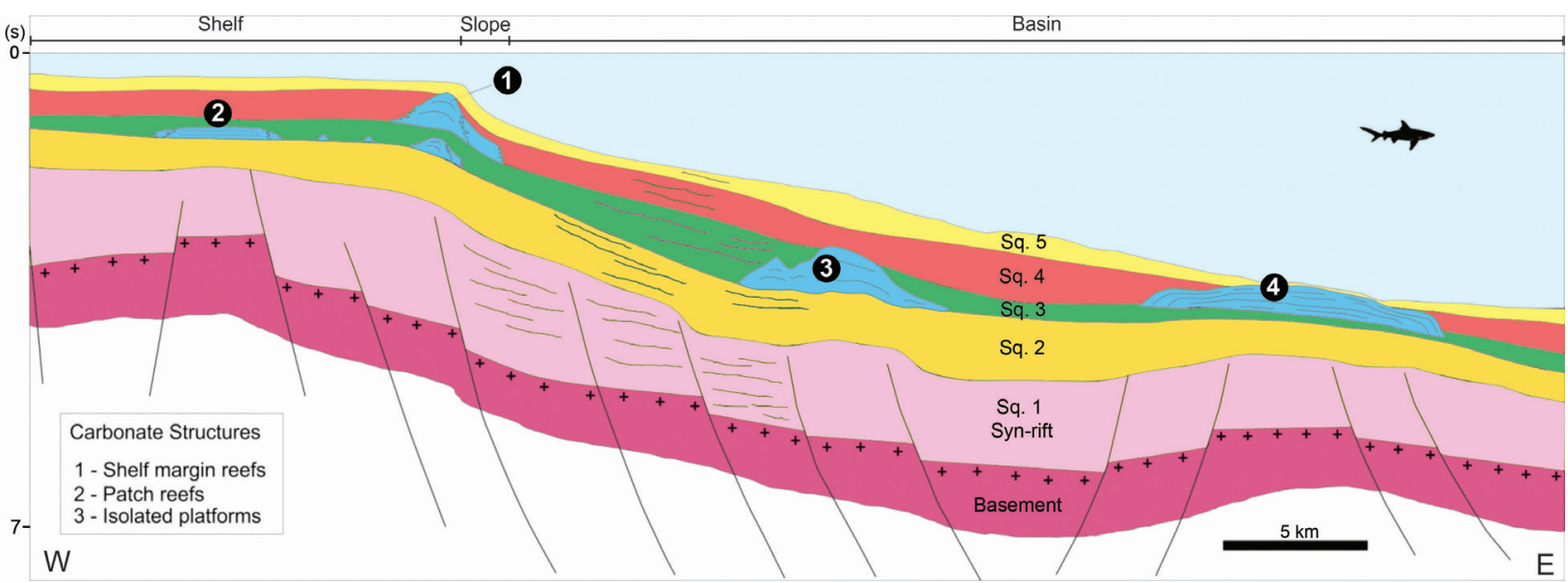

Figure 5 - Schematic geological section across the offshore domains of the PEB based on the interpretation of 2D seismic sections and showing the main interpreted seismic sequences and the stratigraphic position and morphology of the main types of carbonate buildups. The stratigraphic sequences are detailed in Figure 4 (depth in time TWT).
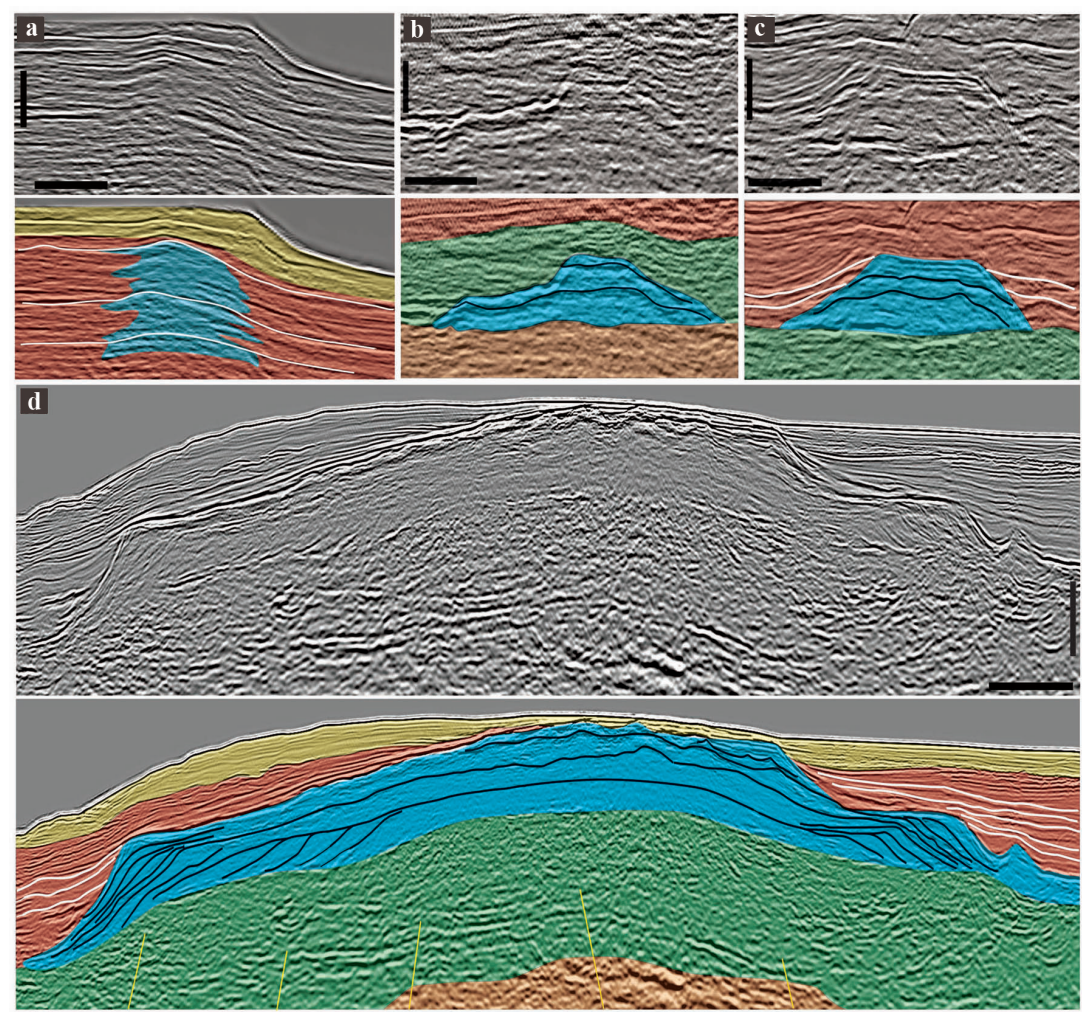

Figure 6 - Carbonate structures observed in seismic sections (interpreted and noninterpreted) of the PEB. Structure locations are shown in Figure 3. a) Shelf margin reef in the border of the Maracatu High showing depositional wings. b) Patch reef located over the Maracatu High. c) Small isolated carbonate platforms. d) Large isolated carbonate platform exhibiting prograding clinoforms over the Gaibu High. Division of seismic sequences: yellow - Sq. 5, red - Sq. 4, green - Sq. 3, orange - Sq. 2. Black lines: stratal surfaces and growth stages. White lines: onlap surfaces. $\mathbf{a}$ and $\mathbf{b}$ vertical scale $0.2 \mathrm{~s}$, horizontal scale $1 \mathrm{~km}$. c vertical scale $0.3 \mathrm{~s}$, horizontal scale $1 \mathrm{~km}$. d vertical scale $0.4 \mathrm{~s}$, horizontal scale $2 \mathrm{~km}$. 
by high-amplitude reflection with a convex-upward shape and show disrupted to chaotic reflections in its interior (Fig. 6b).

The third carbonate buildup type is the isolated carbonate buildups found in the plateau regions (Figs. 3, 6c, d and 7). These large buildups were built over structural highs and paleotopographic highs (outer highs, salt diapirs, and magmatic structures). During the evolution of the plateau, the topographic conditions and sea-level variations most likely enabled the production and deposition of carbonate deposits (Figs. 6d and 7). A total of four isolated carbonate buildups were studied, and their lengths range from 4 to $26 \mathrm{~km}$, widths range from 3.5 to $25 \mathrm{~km}$ and heights range from 0.34 to $0.62 \mathrm{~s}$. The isolated buildups exhibit continuous and high-amplitude seismic reflection at its flat tops and mainly continuous to semi-continuous, medium- to high-amplitude and, in some cases, chaotic or free seismic reflections in their interior. Another important aspect is the upward deflection of the seismic reflector at the base of the buildup, along with underlying reflectors, below the center of some carbonate platforms, as a result of the pullup effect caused by an increase in seismic velocity due to the high-density carbonate rocks.

In a few regions with good coverage of seismic sections, it was possible to interpolate the 2D interpreted horizon related to the top of the isolated carbonate buildups. This allowed us to create a contour map of the top surface, which revealed that these structures possess an elongated morphology with a flat top due to the end of the carbonate buildup growth (Burgess et al. 2013, Koša et al. 2015) (Fig. 8).

\section{DISCUSSION}

Despite the fact that carbonate rocks have been found in two stratigraphic boreholes drilled in the coastal zone of the Pernambuco Basin, related to the Cenomanian-Turonian marls and sandy limestones of Estiva Formation, outcrops of carbonate deposits are scarce in its onshore regions. Thus, the identification of carbonate buildups provided here represents one of the first systematic descriptions of carbonate structures for the offshore domains of this basin. The age claimed here for the carbonate buildups is younger than the age observed for the onshore record, which indicates that favorable conditions for carbonate depositions prevailed until the uppermost Cretaceous and Early Paleogene (Figs. 5, 6 and 7). The lack of Cretaceous post-Turonian and Paleogene deposits in the onshore region of Pernambuco Basin is most likely a result of tectonic uplift and extensive erosion (Lima Filho 1998), which may have removed the record of these carbonate deposits from the proximal part of the basin. Considering extrapolation of the chronostratigraphy on which our interpretation is based, we infer that the age of the described carbonate buildups and isolated platforms are assigned to two main periods/seismic sequences: Sq. 3 Campanian-Maastrichtian and Sq. 4 Paleocene-Middle Miocene (Figs. 5, 6 and 7). Markedly, the ages interpreted here show a correlation with the age of carbonate deposits found in seamounts (Pernambuco Seamounts) located in the oceanic basin to the north of the Pernambuco Plateau (Skolotnev et al. 2012). These authors investigated microfossils found in carbonate rocks dredged from seamounts, the tops of which are $\sim 2400 \mathrm{~m}$ below the relative sea level. They defined the carbonate rocks capping the seamounts as forming during the Campanian-Maastrichtian and Turonian-Santonian. As observed for the now submerged seamounts, topographic highs formed within the plateau reached oceanographic and climatic conditions that enabled expressive carbonate deposition. The inferred age of the carbonate buildups in the offshore Pernambuco Basin suggest that this phase of carbonate deposition occurred during the post-rift period. Certainly, the tectonic conditions generated by Pernambuco 


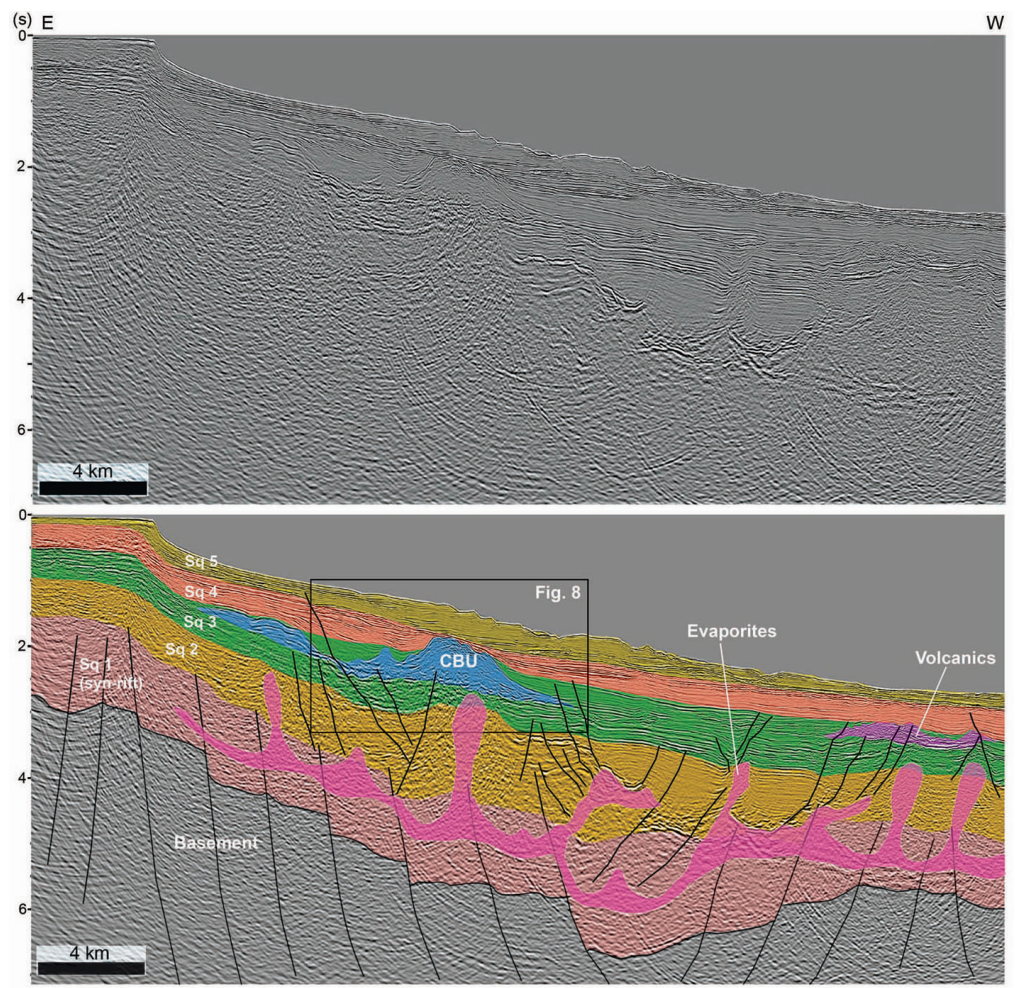

Figure 7 - Seismic section (interpreted and non-interpreted) showing an isolated carbonate platform in the Pernambuco Plateau. The geometry formed below the structure, caused by the velocity pull-up, can be observed. This buildup is not located over a paleotopographic high formed by a basement ridge.

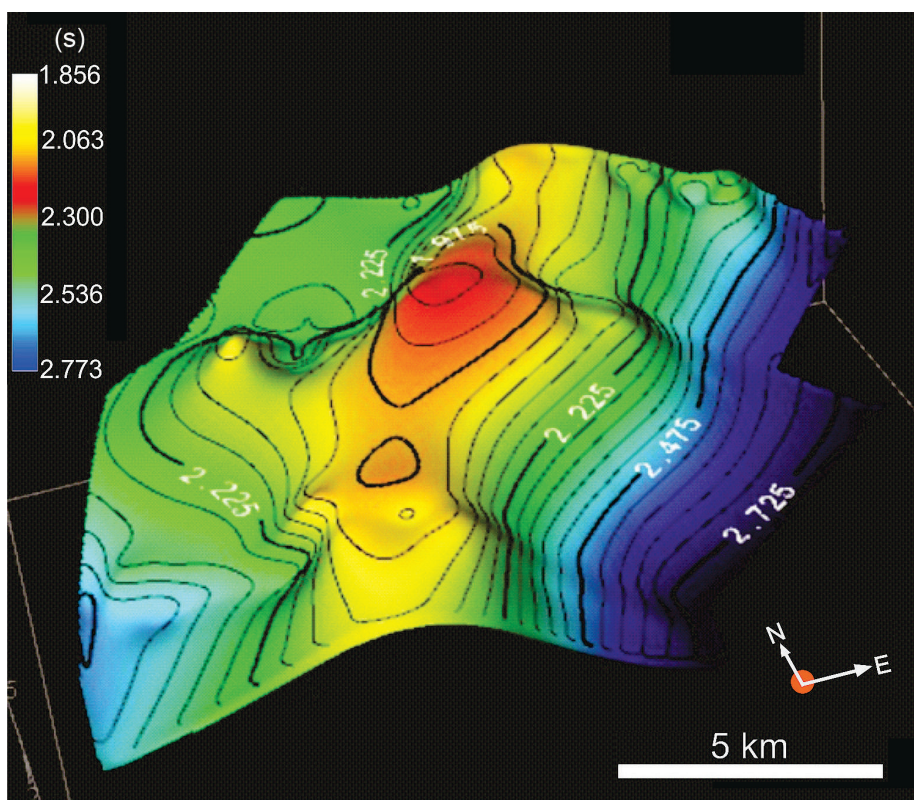

Figure 8 - Contour map of the surface marking the top of the isolated carbonate buildup shown in Figure 6. It exhibits an elongated morphology and a flat top, which differ from other types of structures common in the basin, such as volcanoes. 
Plateau formation provided important parameters for development of these structures. Notably, the major isolated carbonate platforms developed over outer topographic highs, such as the Maracatu High and Gaibu High (Magalhães et al. 2014) (Fig. $3)$. This investigation suggests that development of isolated carbonate platforms offshore of the Pernambuco Basin was directly controlled by the formation of the Pernambuco Plateau, which once led to the creation of topographic highs that created local conditions for carbonate deposition. These same processes are not so important for the neighboring Alagoas Basin, for example, for which the Campanian-Maastrichtian and Paleogene distal sequences are mainly dominated by siliciclastics (Campos Neto et al. 2007).

Our interpretation suggests that the carbonate buildups observed in the seismic sections of Pernambuco Basin show evidence of rapid drowning events (Fig. 6). Drowning events occurred in carbonate buildups in different periods of the post-rift/drift phase (Figs. 6 and 7), according to the proposed age of the sequences (Sq. 3 and Sq. 4) (Fig. 5). Stratigraphic relations show rapid onlap and growth shut down (Figs. 6 and 7) (Erlich et al. 1990). The large isolated platform positioned over the Gaibu High in the central region of the plateau (Fig. 6d) shows evidence of at least three pulses of growth before the complete drowning. It is possible that this large isolated buildup experienced eventual exposure, and consequent erosional events, as indicated by truncation of internal reflectors forming prograding clinoforms (Fig. 6d). The top of this structure, capped by a thin pack of Upper Cenozoic strata,is marked by a high amplitude reflector which shows evidence of truncation.

These carbonate buildups formation, at least within the plateau domains, were influenced by the elevated topography regional structures. However, the influence of relative sea-level changes, and proper subsidence of the plateau in the major drowning events are unclear. Lack of better seismic data and offshore boreholes (chronostratigraphic data) prevents more in-depth considerations about the age of these events, and its correlation with major sea-level excursions that affected the Atlantic. These aspects must be addressed by future investigations.

Large carbonate buildups that formed over outer highs in the pre-salt interval (microbialites formed in the gulf stage of South Atlantic Ocean) represent important prospects in the Santos Basin (São Paulo Plateau), located at the southeast margin of Brazil (Gomes et al. 2011, Boyd et al. 2015). Despite its difference in origin, from an exploratory point of view, the structures described here formed in marine systems during the drift phase of South Atlantic (post-salt interval). Being located over outer basement highs, these structures may represent important oil and gas reservoirs due to the regional effect of focusing migration paths (Burgess et al. 2010, Gomes et al. 2011).

\section{CONCLUSIONS}

Basic interpretation methods and post-processing procedures, including band pass frequency filtering, were applied to a set of 142 multichannel seismic sections that cover a large part of the offshore domain of the Pernambuco Basin in northeastern Brazil. This investigation successfully identified and described three types of carbonate buildups in the basin: 1) shelf margin reefs, which developed inthe Maracatu High along the border of the Pernambuco Basin outer hinge; 2) patch reefs that formed over the Maracatu High along the continental platform behind the shelf margin reefs; and 3) isolated carbonate platforms that developed in the Pernambuco Plateau regions, associated with paleotopographic highs formed by outer basement highs, salt diapirs and magmatic structures. The carbonate buildups described in this investigation were formed within post- 
rift sequences. Considering the inferred ages for the seismic sequences, the carbonate buildups are constrained within two main intervals, the Campanian-Maastrichtian and Paleogene-Middle Miocene. Formation of carbonate buildups in the Pernambuco Plateau domains were controlled by the formation of the plateau, which possibly created local conditions for expressive carbonate deposition during post-rift periods. Stratigraphic relations show that carbonate buildups within the two sequences shows evidence of growth stages and drowning. The causes of drowning could be associated with major Atlantic relative sea-level oscillations, or tectonic events of Pernambuco Plateau evolution. The lack of offshore data prevent more detailed conclusions on these processes.

The findings presented here contribute to understanding the evolution of the Pernambuco Basin and knowledge about the opening of the South Atlantic in this region. Moreover, the information provided by this study is critical for evaluating the petroliferous potential of the Pernambuco Basin. The configuration of carbonate buildups and platforms formed over outer highs within the Pernambuco Plateau has impressive similarities with known large oil reservoirs formed in the presalt interval in the Santos Basin, São Paulo Plateau, in the southeast Brazilian margin.

\section{REFERENCES}

ALMEIDA FF, HASUI Y, BRITO NEVES BB AND FUCK RA. 1981. Brazilian structural provinces: an introduction. Earth Sci Rev 17: 1-29.

ARAUJO CEG, WEINBERG RF AND CORDANI UG. 2013. Extruding the Borborema Province (NE-Brazil): a two stage Neoproterozoic collision process. Terra Nova 26(2): 157-168.

BACHTEL ST, KISSLING RD, MARTONO D, RAHARDJANTO SP, DUNN PA AND MACDONALD BA. 2004. Seismic stratigraphic evolution of the MiocenePliocene Segitiga platform, East Natuna Sea, Indonesia: the origin growth and demise of an isolated carbonate platform. In: Eberli GP, Masaferro JL and Sarg JFR (Eds),
Seismic Imaging of Carbonate Reservoirs and Systems. Memoir, vol. 81. AAPG, Tulsa, p. 309-328.

BARBOSA JA, MAIA MF, LIMA FILHO M, MAGALHÃES JR AND CORREIA FILHO OJ. 2014. Seismic stratigraphy of the onshore portion of Pernambuco Basin: evidence of break up during Middle Albian for the south Atlantic rift in Northeast Brazil. In: AAPG Annual Exhibition and Convention, Houston.

BARBOSA JA, PEREIRA PJF AND LIMA FILHO MF. 2008. Dente de um picnodontiforme (Actinopterygii, Neopterygii) da Formação Estiva, CenomanianoTuroniano da Bacia de Pernambuco, NE do Brasil. Gaea (São Leopoldo Online) 4: 43-48.

BOSENCE D. 2005. A genetic classification of carbonate platforms based on their basinal and tectonic settngs in the Cenozoic. Sediment Geol 175: 49-72.

BOYD A, SOUZA A, CARNEIRO G, MACHADO V, TREVIZAN W, SANTOS B, NETTO P, BAGUEIRA R, POLINSKI R AND BERTOLINI A. 2015. Presalt carbonate evaluation for Santos Basin, offshore Brazil. Petrophysics 56(6): 577-591.

BUARQUE BV, BARBOSA JA, MAGALHÃES RG, OLIVEIRA JTC AND FILHO OC. 2016. Post-rift volcanic structures of the Pernambuco Plateau, northeastern Brazil. J S Am Earth Sci 70: 251-267.

BURGESS PM, WINEFIELD P, MINZONI M AND ELDERS C. 2013. Methods for identification of isolated carbonate buildups from seismic reflection data. AAPG Bulletin 97(7): 1071-1098.

CAMPBELL AE AND STAFLEU J. 1992. Seismic modeling of an Early Jurassic, drowned carbonate platform: Djebel Bou Dahar, High Atlas, Morocco. AAPG Bulletin 76(11): 1760-1777.

CAMPOS NETO OPAC, LIMA WS AND CRUZ FEG. 2007. Bacia de Sergipe-Alagoas. Bol Geocienc Petrobras 15(2): 405-415.

CHANG HK, KOWSMANN RO, FIGUEIREDO AMF AND BENDER AA. 1992. Tectonics and Stratigraphy of the East Brazil Rift system: an overview. Tectonophysics 213: 97-138.

CÓRDOBA VC, JARDIM DE SÁ EF, SOUSA DC AND ANTUNES AF. 2007. Bacia de Pernambuco- Paraíba. Bol Geocienc Petrobras 15(2): 391-403.

COURGEON S, BOURGET J AND JORRY SJ. 2016. A Pliocene-Quaternary analogue for ancient epeiric carbonate settings: The Malita intrashelf basin (Bonaparte Basin, northwest Australia). AAPG Bulletin 100(4): 565595.

ERLICH RN, BARRETT SF AND JU GB. 1990. Seismic and geologic characteristics of drowning events on carbonate platforms. AAPG Bulletin 74(10): 1523-1537. 
FAINSTEIN R AND MILLIMAN JD. 1979. Structure and origin of three continental-margin plateaus, northeastern Brazil. AAPG Bulletin 63(2): 218-238.

FEIJÓ FJ. 1994. Bacias de Sergipe e Alagoas. Bol Geocienc Petrobras 8(1): 149-216.

FULTHORPE CS AND SCHLANGER SO. 1989. Paleooceanographic and tectonic settings of early Miocene reefs and associated carbonates of offshore Southeast Asia. AAPG Bulletin 73: 729-756.

GOMES PO, GOMES BS, PALMA JJC, JINNO K AND SOUZA JM. 2000. Ocean-continent Transition and Tectonic Framework of the Oceanic Crust at the Continental Margin of Northeast Brazil: Results of LEPLAC Project. In: Monography Series, 15. American Geophysical Union, p. 261-291.

GOMES PO, KILSDONK B, GROW T, MINKEN J AND BARRAGAN R. 2011. Tectonic evolution of the Outer High of Santos Basin, Southern São Paulo Plateau, Brazil, and implications for hydrocarbon exploration. In: Gao D (Ed), Tectonics and sedimentation: Implications for petroleum systems. AAPG Memoir 100: 1-14.

JAMALUDIN SNF, PUBELLIER M AND MENIER D. 2014. Relationship syn-depositional faulting and carbonate growth in Central Luconia Province, Malaysia. GSM Bulletin 60: 77-83.

KOŠA E, WARRLICH GMD AND LOFTUS G. 2015. Wings, mushrooms, and Christmas trees: The carbonate seismic geomorphology of Central Luconia, Miocene-present, offshore Sarawak, northwest Borneo. AAPG Bulletin 99(11): 2043-2075.

KOUTSOUKOS EAM. 1989. Mid to late cretaceous microbiostratigraphy, paleo-ecology and paleogeography of the Sergipe Basin, northeastern Brazil, 645 p. PhD. thesis - Department of Geological Sciences of Polytechnics South West, Plymouth.

KUSUMASTUTI A, VAN RENSBERGEN P AND WARREN JK. 2002. Seismic sequence analysis and reservoir potential of drowned Miocene carbonate platforms in the Madura Strait, East Java, Indonesia. AAPG Bulletin 86(2): 213-232.

KUZNETSOV VG. 1997. Oil and gas in reef reservoirs in the former USSR. Pet Geosci 3: 65-71.

LIMA MR AND PEDRÃO E. 1989. Análise palinológica de sedimentos da Bacia do Cabo, Cretáceo do Estado de Pernambuco, Brasil. An Acad Bras Cienc 61:73-84.

LIMA FILHO MF. 1998. Análise Estrutural e Estratigráfica da Bacia Pernambuco (Tese de Doutorado). Instituto de Geociências, Universidade de São Paulo-USP, São Paulo, $139 \mathrm{p}$.

LONG LE, SIAL AN, NEKVASIL H AND BORBA GS. 1986. Origin of Granite at Cabo de Santo Agostinho, Northeast Brazil. Contrib Mineral Petrol 92: 341-350.
MABESOONE JM AND ALHEIROS MM. 1993. Evolution of the Pernambuco-Paraíba-Rio Grande do Norte Basin and the problem of the south Atlantic connection. Geol Mijnb 71: 351-362.

MAGALHÃES JR, BARBOSA JA, OLIVEIRA JTC AND LIMA FILHO MF. 2014. Characterization of the oceancontinent transition in the Paraíba Basin and Natal platform region, NE Brazil. Rev Bras Geofísica 32(3): 481-496.

MAIA MFB. 2012. Revisão Estratigráfica do Intervalo Aptiano-Albiano da Bacia de Pernambuco Nordeste do Brasil (Dissertação de Mestrado). Programa de PósGraduação em Geociências, Departamento de Geologia, Universidade Federal de Pernambuco, Recife, Brazil, 226 p. (Unpublished).

MAIA MFB, BARBOSA JA, LIMA FILHO M, MORT HP AND SANTANA FR. 2012. Características petrográficas e geoquímicas das formações siliciclásticas (AptianoAlbiano) da Bacia de Pernambuco, NE do Brasil. Estud Geol 22(1): 55-75.

MATOS RMD. 1999. History of the northeast Brazilian rift system: kinematic implications for the break up between Brazil and west Africa. In: Cameron NR, Bate RH and Clure VS (Eds), The Oil and Gas Habitats of the South Atlantic. Geol Soc Spec Pub 153: 55-73.

MELVILLE P, AL JEELANI O, AL MENHALI S AND GRÖTSCH J. 2004. Three-dimensional seismic analysis in the characterization of a giant carbonate field, onshore Abu Dhabi, United Arab Emirates. Seismic imaging of carbonate reservoirs and systems: AAPG Memoir 81: 123148.

MENIER D, PIERSON B, CHALABI A AND TING KK. 2014. Morphological indicators of structural control, relative sea-level fluctuations and platform drowning on present-day Miocene carbonate platforms. Mar Petrol Geol 58: 776-788.

MME/EPE. 2012. Zoneamento Nacional de Recursos de Óleo e Gás. Atualização 2011/ Ministério de Minas e Energia, Empresa de Pesquisa Energética, Brasília.

NASCIMENTO MAL. 2003. Geologia, geocronologia, geoquímica e petrogênese das rochas ígneas cretácicas da província magmática do Cabo e suas relações com as unidades sedimentares da Bacia de Pernambuco, NE do Brasil (Tese de Doutorado). Programa de Pós-Graduação em Geologia e Geodinâmica, Universidade Federal do Rio Grande do Norte, Natal, Brazil, 264 p.

NEVES SP, MONIÉ P, BRUGUIER O AND SILVA JMR. 2012. Geochronological, thermochronological and thermobarometric constraints on deformation, magmatism and thermal regimes in eastern Borborema Province (NE Brazil). J S Am Earth Sci 38: 129-146.

OLIVEIRA JTC. 2013. Análise integrada de dados geofísicos da transição crustal (continente-oceano) da Bacia de Pernambuco, NE do Brasil (Dissertação de 
Mestrado). Programa de Pós-Graduação em Geociências, Universidade Federal de Pernambuco, Recife, Brazil, 65 p. (Unpublished).

PLETSCH T, ERBACHER J, HOLBOURN AEL, KUHNT W, MOULLADE M, OBOH-IKUENOBEDE FE, SCODING E AND WAGNER T. 2001. Cretaceous separation of Africa and South America: the view from the West African margin (ODP Leg 159). J S Am Earth Sci 14: 147-174.

POLÔNIA JAP. 1997. Geometria e cinemática do Rifte do Cabo, litoral Sul do Estado de Pernambuco (Dissertação de Mestrado). Programa de Pós-Graduação em Geologia, Universidade Federal do Rio de Janeiro, Brasil, 156 p. (Unpublished).

POMAR L. 2001. Types of carbonate platforms: a genetic approach. Basin Research 13: 313-334.

RAND HM AND MABESOONE JM. 1982. Northeastern Brazil and the final separation of South America and Africa. Paleogeogr Paleoclimatol Paleoecol 38(3-4): 163183.

ROHRMAN M. 2007. Prospectivity of volcanic basins: trap delineation and acreage de-risking. AAPG Bulletin 91(6): 915-939.

RONCHI P, ORTENZI A, BORROMEO MC AND ZEMPOLICH WG. 2010. Depositional setting and diagenetic processes and their impact on the reservoir quality in the late Visean-Bashkirian Kashagan carbonate platform (Pre-Caspian Basin, Kazakhstan). AAPG Bulletin 94(9): 1313-1348.

ROSLEFF-SOERENSEN B, REUNING L, BACK S AND KUKLA P. 2012. Seismic geomorphology and growth architecture of a Miocene barrier reef, Browse Basin, NWAustralia. Mar Petrol Geol 29: 233-254.

SALLER AH, WALDEN S, ROBERTSON S, NIMS R, SCHWAB J, HAGIWARA H AND MIZOHATA S. 2004. Three-dimensional seismic imaging and reservoir modeling of an Upper Paleozoic "Reefal" Buildup, Reinecke Field, West Texas, United States. Seismic imaging of carbonate reservoirs and systems: AAPG Memoir 81: 107-122.

SANTOS EJ, VAN SCHMUS WR, KOZUCH M AND BRITO NEVES BB. 2010. The Cariris Velhos tectonic event in Northeast Brazil. J S Am Earth Sci 29(1): 61-76.
SAQAB MM AND BOURGET J. 2015. Controls on the distribution and growth of isolated carbonate buildups in the Timor Sea (NW Australia) during the Quaternary. Mar Petrol Geol 62: 123-143.

SARG JFR, WEBER LJ, MARKELLO JR, SOUTHWELL JK, THOMSON JM, KMECK JJ, CHRISTAL ME AND TANAKA Y. 1995. Carbonate sequence stratigraphy: A summary and perspective with case history, Neogene, Papua New Guinea, in Proceedings of the International Symposium on Sequence Stratigraphy in SE Asia: Jakarta, Indonesia, Indonesian Petroleum Association, p. 137-179.

SCHLAGER W. 2005. Carbonate sedimentology and sequence stratigraphy: SEPM Concepts in Sedimentology and Paleontology Series 8, $200 \mathrm{p}$.

SIAL AN, LONG LE AND BORBA GS. 1988. Cretaceous Magmatic Province of Cabo, Pernambuco, Northeast Brazil. Rev Bras Geociências 4(17): 667-673.

SKOLOTNEV AA, PEYVE EV, IVANOVA IO, MURDMAA OV AND LEVCHENKO ME. 2012. New Data on Composition and Structure of the Pernambuco Seamounts, Brazil Basin, South Atlantic Region Bylinskaya. Doklady Akademii Nauk 443(3): 330-336.

SUN SQ AND ESTEBAN M. 1994. Paleoclimatic controls on sedimentation diagenesis and reservoir quality: lessons from Miocene carbonates. AAPG Bulletin 78: 519-543.

VAN SCHMUS WR, OLIVEIRA EP, SILVA FILHO AF, TOTEU SF, PENAYE J AND GUIMARÃES IP. 2008. Proterozoic links between the Borborema Province, NE Brazil, and the Central African fold belt. In: Pankhurst RJ, Trouw RAJ, Brito Neves BB and De Wit MJ (Eds), West Gondwana: Pre-cenozoic Correlations across the South Atlantic Region, Geological Society, London, Special Publications, 294, p. 69-99.

WILSON MEJ. 2002. Cenozoic carbonates in Southeast Asia: implications for equatorial carbonate development. Mar Geol 147: 295-428.

ZAMPETTI V, SCHLAGER W, KONJIENBURG JH AND EVERTS AJ. 2004. Architecture and growth history of a Miocene carbonate platform from 3D seismic reflection data: Luconia province, offshore Sarawak, Malaysia. Mar Petrol Geol 21: 517-534. 